\title{
The Cultivation of "Double Excellence in Quality and Skill" Innovation Talents in Vocational Colleges by Focusing on "Craftsman Spirit"
}

\author{
Minhong Dai, Ruizhi Ma and Baochun Zhao \\ Qionghai City, Hainan province China Fu Road No. 128 Hainan College of Software Technology \\ 39913945@qq.com, 70737632@qq.com, 277433225@qq.com
}

Keywords: Craftsman; Spirit; Double excellence in quality and skill; Innovation

\begin{abstract}
Nowadays some students are confronted with the problems of the lack of professional self-identity, effective mechanism of vocational education and the defective professional ethics for some vocational schools only focus on the cultivation of skills. Actually, the cultivation of students' employment ability is largely the integration of professional quality and vocational skills. Based on the quality and capacity requirements for the innovation talents in the enterprises, this paper explores the the construction plan and feasibility of the double excellence in quality and skill talents and discusses the concrete practice of the integration of craftsman spirit into vocational courses and the construction of curriculum evaluation system. through the combination of studio modular curriculum construction in HAINAN College of Software Technology.
\end{abstract}

\section{Introduction}

With the development of the times, the demand of enterprises for talents not only reflects in the skills and qualifications, but the students' professionalism, especially the craftsman spirit, so how to cultivate talents with double excellence in quality and skill in Hainan vocational college by focusing on the craftsman spirit has become a problem that needs to be concerned and explored. Based on the background of school-enterprise integration and the craftsman spirit, HAINAN College of Software Technology has found the importance of student skills and personnel cultivation and digital design of animation production technology professional has set up a number of school-enterprise cooperation studios, such as master studio, Shihu studio, which provide a good business environment for the cultivation of craftsman spirit and reform path for the innovation talents with double excellence in quality and skill in HAINAN College of Software Technology.

\section{Connotation of Craftsman Spirit and Importance of Cultivating 'Double Excellence in Quality and Skill' Innovation Talents}

Craftsman spirit(1)refers to our well-seasoned and constant improvement attitudes in work and life. To have the spirit of craftsman really, we must be focused, concentrate, professional, refinement, innovation and excellence. The spirit of craftsman enhances the school-running concept and contents and improve the cultivation purpose and objectives from the development needs of vocational schools. The spirit of craftsman adds the connotation of the times for the students professionalism and quality cultivation in vocational college students, such as the establishment of studio teaching in our school. Actually it is precisely the cultivation of the craftsman spirit makes the smooth development of leading modular teaching reform of the real cartoon production project.

\section{Demand Analysis of Hainan Enterprises on the 'Double Excellence in Quality and Skill' Innovative Talents' Abilities in Vocational Colleges}

With the construction of Hainan's 13th Five-Year Plan, there are still few talents with double excellence in quality and skill in enterprises. After the survey of a number of local recruitment enterprises in Hainan Province, the enterprises prefer students in vocational colleges. Based on the 
research, high school graduates account for nearly 50\%, 31\% of undergraduate, which can see that students graduated from vocational colleges have more advantages than those undergraduates. It is very important and necessary to carry forward the spirit of craftsman and cultivate students in vocational college to be innovative talents both excellence in quality and professional skills.

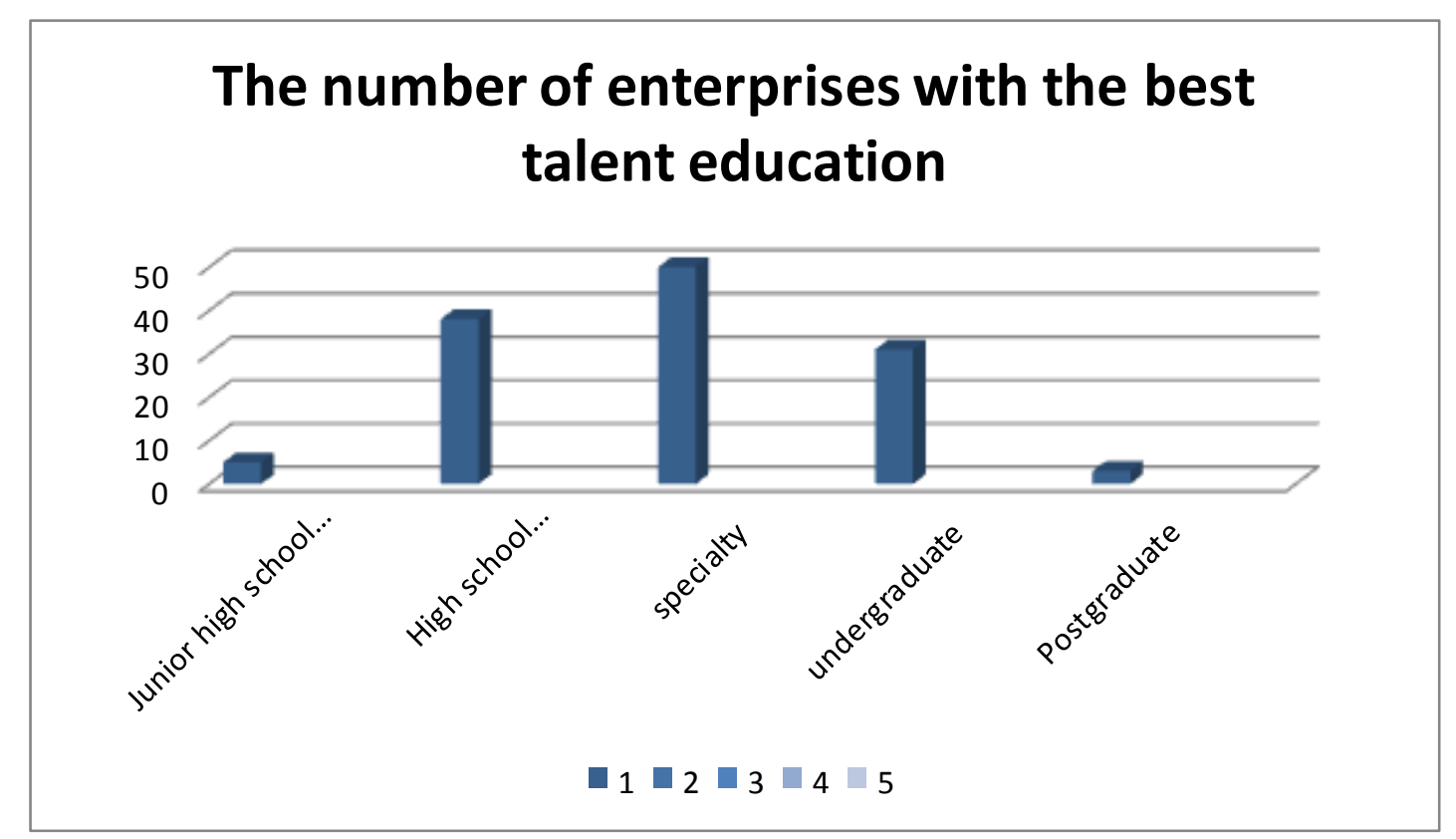

Figure 1

The essence of the craftsman spirit is to promote dedication, so we investigate the enterprise recruiters professionalism, work experience and educational level and the statistical results shown in Figure 2, 69\% of people pay more attention to professionalism. While $19 \%$ of people focus on the work experience, they feel that students practical experience of participating in the actual project can increase their employment rates; $12 \%$ of people stress educational level, a high level of education can bring more solid basic knowledge.

This shows that professionalism is one of the important manifestations of the spirit of craftsmen, to become innovation talents with double excellence in quality and skill, graduates must have a clear goal and work conscientiously, efficiently and hardly. Only a good attitude in work can obtain the employment of enterprises, which put much more emphasis on "quality" than the "skill". 


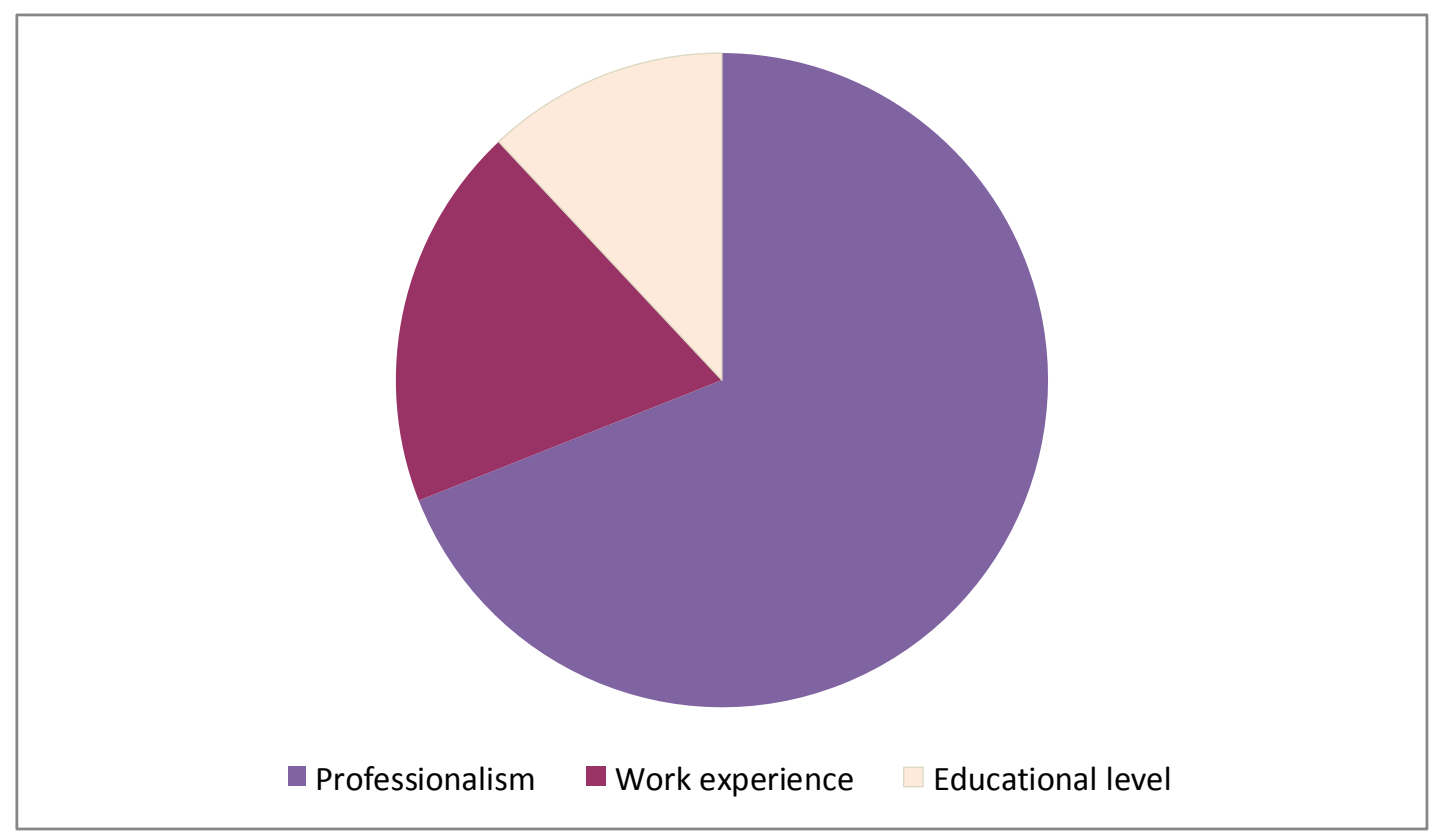

Figure 2

\section{Cultivation Scheme and Implementation of Talents with Double Excellence in Quality and Skill in Hainan Vocational Colleges by Focusing on Craftsman Spirit}

Employ Teachers to Nurture the Craftsman Spirit and Strengthen the Teaching Staff with Enterprise Experience. Adhere to the principle that" introducing craftsman into the school, cultivating backbone teachers craftsman spirit and combining business teachers and backbone teachers" ,explore enterprises new situation to employ the craftsman, arrange the backbone teachers regularly to the enterprises for practice training, use enterprise staff to train school teachers, adopt "mutual employment and communication", develop team building and teacher training plan and the accumulation of professional teachers work experience and the craftsman spirit professionalism; also take active measures to improve the proportion of teaching tasks of teachers with craftsman spirit from production line. For instance, to invite the animation master in Chinese Opera Institute to set up master studio in Hainan universities and colleges, enterprise teachers can influence greatly teachers while guiding them, so the best way to learn is to learn from the best.

Perfect "School-enterprise Integration" and "Technology Integration" System Construction in Vocational Schools. Establish an effective teaching mechanism with the craftsman spirit, actively promote the school-enterprise technical research and system construction of enterprise culture exchange, deepen the core of enterprise culture, expand the forms enterprise culture integrating into vocational schools through the school-enterprise cooperation; In the training process, such as the lectures jointly held by our studio and the enterprise can elaborate on the importance of craftsman spirit for the enterprises, and strengthen the students' sense of responsibility and dedication; to jointly develop teaching materials and courses on cultivating innovative high-skilled personnel with enterprises, make students feel the business environment in the learning process at any time, and the spirit of craftsman penetrate the training of innovative skilled talents.

Integration of Studio Modular Teaching Contents of Craftsman Spirit. The purpose of craftsman spirit is to cultivate innovative professional and technical personnel and vocational schools must integrate the spirit of craftsman into the studio modular curriculum, for example, to analyze the concept of craftsman spirit and connotation and understand the basic content in our master studio professional quality courses. In module course, such as animation character design module and animation scene design module, we set up every link and emphasize the standard and meticulous according to enterprise industry norms and requirements in the curriculum module. In 
the courses, the studio achieves all curriculum link and each people have the sense of responsibility and team awareness. In other professional courses, we focus on the integration of good corporate culture, staff quality, quality, safety operating practices, fine management, production attitude and job responsibilities.

Integration of Excellent Corporate Culture and Modularized Curriculum and Teaching Material Construction. The integration of craftsman spirit and corporate culture into the construction of higher vocational textbooks can help students have more clear career goals and sense of belonging. The integration of corporate culture and modular curriculum materials is conducive to promoting the spirit of craftsmen in the campus and the classroom, and spreading excellent corporate culture and craftsmen spirit in the whole process of vocational education. Also the training cases of craftsman spirit into textbooks can further expand the student's learning horizons and spiritual realm.

Strengthen Course Evaluation System in the Professional Competence. Craftsman spirit is the core of professional competence strengthening, so establishing a positive evaluation-oriented mechanism, integrating the craftsman spirit into the talent evaluation system, describing and extracting the enterprise professional competence with evaluation factors are very necessary. The craftsman spirit is integrated into the evaluation factors illustrated by the case of school-enterprise cooperation(2) innovation and entrepreneurship base in Hainan vocational colleges, as shown in Table 01 below:

Table 1

\begin{tabular}{|c|c|}
\hline $\begin{array}{c}\text { Related standards } \\
\text { of post }\end{array}$ & Description of evaluation factors \\
\hline $\begin{array}{l}\text { Sense of } \\
\text { responsibility for } \\
\text { work } 15 \%\end{array}$ & $\begin{array}{l}\text { 1.Be willing to take responsibility for the work result; } \\
\text { 2.Complete attendance and without casual absenteeism; }\end{array}$ \\
\hline Work quality $30 \%$ & $\begin{array}{l}\text { 1.Provide maximum convenience for the follow-up work; } \\
\text { 2.Comply with regulations and business rules; } \\
\text { 3.Maintain the stability of learning status and work quality without } \\
\text { the supervision }\end{array}$ \\
\hline \multirow{2}{*}{$\begin{array}{l}\text { Work } \\
\text { efficiency } 15 \%\end{array}$} & $\begin{array}{l}\text { 1.Take the initiative to adjust and speed up according to the needs; } \\
\text { 2.Complete the taskon time }\end{array}$ \\
\hline & $\begin{array}{l}\text { 1.Have a good understanding of work task requirements; } \\
\text { 2.Have the necessary work knowledge, skills and methods to } \\
\text { independently complete the work. }\end{array}$ \\
\hline Teamwork10\% & $\begin{array}{l}\text { 1.Make the necessary dedication for the team interest; } \\
\text { 2.Willingness to share experience and views with others; } \\
\text { 3.Teamwork spirit. }\end{array}$ \\
\hline
\end{tabular}

The above indicators set can reflect that the craftsman spirit has a higher evaluation weight in the core related professional qualities. Professional assessment needs to establish the training objectives in accordance with professional quality, reform curriculum, test content and evaluation elements, and continuously improve the craftsman spirit in vocational schools and achieve evaluation 
mechanism and make students become innovative talents with double excellence in quality and skill.

\section{Inheritance Problems of Craftsman Spirit}

Existing Problems. The proportion of enterprise staff with "craftsman spirit" is very small in Hainan vocational schools. In recent years, the closer interaction between schools and enterprises makes more craftsmen into the classroom of Hainan vocational schools, but not perfect employment policy and the proportion still affect high technical personnel training.

Teachers in Hainan vocational schools relatively lack practical experience in production on the "spirit of craftsman", the most valuable attitude needs to be further improved.

The cultivation in vocational schools of students' skills, experience and attitude lacks the complete knowledge of the industry chain and skills, so business simulation environment needs to be improved.

Development Strategies. Increase the introduction of skilled craftsmen, explore the incentives and employment system, for instance, the establishment of skilled teacher positions and recruitment of skilled craftsmen with practical experience into the Hainan universities and colleges can bring professional vitality, and comprehensively enhance the professional competitiveness.

Increase the construction of teaching staff and schools- enterprises interaction to conduct the in-depth study for the enterprise technology, production processes, corporate culture, and the embodiment of craftsman spirit.

Vocational schools should cooperate with enterprises to hold the second classroom, to visit enterprises, interview with corporate positions, employment stars, can help students understand the value of the spirit of craftsman in the enterprise, and hire business experts to do a detailed explanation and analysis. Employment stars and other outstanding graduates can be models to influence and guide students positively through the experience of cultivating the craftsman spirit.

\section{Conclusion}

During the 13th Five-Year Plan period, the innovative talents with double excellence in quality and skill have become the key demand in Hainan, but the cultivation of craftsman spirit still has a long way to go. Only graduates have and carry forward the craftsman spirit in Hainan vocational colleges can open up new horizons in the future workplace. We should further cultivate innovation personnel with double excellence in quality and skill to help the development of vocational education in Hainan by focusing on the spirit of craftsman.

\section{Annotations}

(1)(Yang Zhiping): Reshape the Spirit of Craftsman, Chinese Clothing, (the seventh issue of 2015), page 1.

(2)(Wang Haiyun): Remodeling the Spirit of Luban, Money China,( the 13th issue of 2015), page 23.

(3)(Yang Songlu): Reflections on the Cultivation of Youth 's Core Values, Beijing Youth Research, (People's Publishing House), (the fourth issue of 2014), page 86-91. 


\section{References}

[1] Xiao Qunzhong, Liu Yongchun. Craftsman Spirit and Its Contemporary Value [J]. Hunan Social Sciences, 2015, 06:6-10.

[2] Ye An, Liu Lin. Red Culture and Cultivation of Contemporary Craftsman in Vocational Colleges[J]. Vocational \& Technical Education Forum, 2015, 34: 80-85.

[3] Zha Guoshuo. Modern Value Implication of Craftsman Spirit [J]. Vocational \& Technical Education Forum, 2016, 07: 72-75.

[4] Wang Xinyu. Cultivation of Higher Vocational Students' "Craftsmanship" in the View of "Made in China"[J]. Vocational Education Research, 2016, 02: 14-17.

[5] Kong Baogen. Practical Ways of Cultivating "Spirit of Craftsman" in Higher Vocational Colleges[J]. Journal of Ningbo University (Educational Science Edition),2016,03:53-56. 